Article

\title{
Provitamin A Carotenoids, Tocopherols, Ascorbic Acid and Minerals in Indigenous Leafy Vegetables from Tanzania
}

\author{
Victoria Flavian Gowele ${ }^{1,2, *}$, Joyce Kinabo ${ }^{1}$, Theresia Jumbe ${ }^{1} \oplus$, Carolyn Kirschmann ${ }^{2}$, \\ Jan Frank ${ }^{2}$ and Wolfgang Stuetz ${ }^{2}$ iD \\ 1 Department of Food Technology Nutrition and Consumer Sciences, College of Agriculture, \\ Sokoine University of Agriculture, P.O. Box 3006, Morogoro, Tanzania; joyce_kinabo@yahoo.com (J.K.); \\ tjumbe2000@yahoo.com (T.J.) \\ 2 Institute of Nutritional Sciences, University of Hohenheim, Garbenstr. 28, 70599 Stuttgart, Germany; \\ carolyn.kirschmann@gmx.net (C.K.); jan.frank@nutres.de (J.F.); wolfgang.stuetz@uni-hohenheim.de (W.S.) \\ * Correspondence: vgowele@sua.ac.tz; Tel.: +255-784451020
}

Received: 4 December 2018; Accepted: 27 December 2018; Published: 19 January 2019

\begin{abstract}
The essential micronutrients in indigenous leafy vegetables (ILVs) could substantially contribute to the micronutrient supply in rural communities in Tanzania, but concentrations differ between species. Provitamin A carotenoids, tocopherols, ascorbic acid, minerals, and phytate were analysed in 13 different species using HPLC-, ICP-OES, and photometric techniques. Eight of the 13 ILVs, including Amaranthus ssp. and Sesamum angustifolium, had high $\beta$-carotene concentrations (2.91-4.84 mg/100 g fresh weight), which could provide $\geq 50 \%$ of vitamin A's recommended nutrient intake (RNI). Six ILVs including Cleome hirta and Sonchus luxurians had high iron contents (34.5-60.4 mg/100 g, >50\% RNI); Amaranthus ssp. represented the ILV with high calcium, magnesium and zinc contents $(85 \%, 207 \%$ and $21 \%$ of RNI per $100 \mathrm{~g})$; Cleome hirta and Cleome gynandra had high ascorbic acid contents (>15 mg/100 g, 34-35\% of RNI), while Sesamum angustifolium was the only ILV with a high tocopherol content $(7.34 \mathrm{mg} \alpha$-TE/100 g). The highest phytate concentration was found in Amaranthus ssp., which could negatively affect its role as a very good source of minerals. Results indicate that the analysed ILVs could make a substantial contribution to the vitamin A and iron supply in the diets of rural Tanzanian populations.
\end{abstract}

Keywords: leafy vegetables; micronutrients; carotenoids; nutrient intake; Tanzania

\section{Introduction}

Indigenous leafy vegetables (ILVs) are acknowledged as part of a healthy diet due to their contribution to the dietary requirements of essential micronutrients such as vitamin A and C, iron, zinc, calcium, and magnesium [1-3]. Half of vitamin A and one-third of iron requirements in rural Tanzanian households are obtained through the consumption of indigenous leafy vegetables [4]. The typical daily main meal in Tanzania is made up of a cereal food such as rice or stiff porridge (ugali) made from maize or pearl millet flour, and is usually accompanied by a serving of cooked green leafy vegetables. These green leafy vegetables can be homegrown, bought at local markets, or harvested from the wild as indigenous species $[4,5]$. The term "indigenous" in this case refers to a crop species or variety genuinely native to a region, or to a crop introduced into a region where over a period of time it has evolved, although the species may not be native [4]. ILVs grow as weeds in the wild or in cultivated areas, but have also been domesticated through semi-cultivation or cultivation [6]. In addition, ILVs thrive with minimal care, are inexpensive, easily accessible, easy to cook, and could play an important role in ensuring micronutrient supply [3,7-10]. ILVs with high concentrations of provitamin A carotenoids 
and iron could essentially contribute in the reduction of vitamin A and iron deficiencies in rural areas where the diet is low in animal source foods [11]. The Tanzania Demographic and Health Survey in 2010 revealed a high prevalence of iron $(>29 \%)$ and vitamin A deficiency $(>35 \%)$ in women aged 15-49 years [12]. The present study is part of the 'Scaling Up Nutrition' project (www.scale-n.org) which focus on the development of nutrient-sensitive strategies to improve nutrition and health status of small-scale-farmer in Dodoma and Morogoro regions; in these areas ILVs are already part of the daily diet, but detailed data on the concentrations of individual provitamin A carotenoids, vitamins and minerals in the different species are inadequate. Therefore, thirteen species of ILVs were collected from the study areas in Chamwino and Kilosa districts in order to analyse the profile of micronutrients including provitamin A carotenoids, tocopherols, ascorbic acid, and the minerals iron, zinc, magnesium, and calcium. In addition, the concentration of phytate (phytic acid-inositol hexakisphosphate) as a naturally occurring anti-nutritional factor known to affect the bioavailability of minerals was determined [10].

\section{Materials and Methods}

\subsection{Description of the Study Area}

The study was conducted in Dodoma and Morogoro regions in Tanzania. One district from each region was selected, Chamwino district in Dodoma and Kilosa district in Morogoro. Mzula and Chinoje villages in Chamwino and Tindiga and Mhenda villages in Kilosa district were selected based on factors such as geographical location, climate and consumption pattern of different indigenous vegetables (www.scale-n.org). Chamwino is located in the central plateau of Tanzania characterized by a dry Savannah and periodically semi-arid type of climate with long dry season starting late April to early December, and a short single wet season starting December to mid-April. The annual rainfall is between $350-500 \mathrm{~mm}$. Kilosa District is located in eastern Tanzania characterized with sub-humid climatic condition with short rains starting in October to December and long rainfall period begin in February to May. This area has flat plains, highlands, and dry alluvial valleys with annual rainfall between $600-800 \mathrm{~mm}$ [13].

\subsection{Sample Collection and Preparation}

Thirteen different species of indigenous leafy vegetables were collected from their natural habitat during the wet season in April 2016 (Kilosa samples) and March 2017 (Chamwino samples), as shown in Table 1. Selection of the vegetable species for our research was based on the focus group discussion findings in the study areas where most women mentioned their wider consumption by the community. Identification of the vegetable samples was done by a botanist from the Department of Crop Science and Horticulture at Sokoine University of Agriculture (SUA).

The leafy edible parts of the vegetables were separated from the main plant, washed with running tap water, air-dried at room temperature at the study sites, placed in black polyethylene bags, and subsequently transported to the laboratory at SUA. The first batch of samples from Kilosa were kept from April 2016 to August 2016 in a $-30{ }^{\circ} \mathrm{C}$ freezer then transported on dry ice to the University of Hohenheim, Stuttgart in Germany; stored at $-80{ }^{\circ} \mathrm{C}$, freeze-dried, and analysed in September 2016. The second batch of samples from Chamwino were kept for two days in a $-30{ }^{\circ} \mathrm{C}$ freezer, then immediately transported on dry ice to the University of Hohenheim, Stuttgart in Germany; stored at $-80{ }^{\circ} \mathrm{C}$ for one week, then freeze-dried and analysed. The individual ILV species from both sample batches, were freeze-dried for $24 \mathrm{~h}$ (to constant weight), protected from light (using aluminium foil) using a Telstar freeze drier (2014 model LyoQuest; Telstar, Spain), ground in a mortar to a fine homogenous powder and stored in airtight containers protected from light; aliquots of the (freeze-dried) powder were finally weighed as samples for individual analyses on micronutrients and phytate contents. Details regarding botanical names, local names, villages of collection, and the conversion factors of the analysed ILVs are given in Table 1. Samples were weighed before and after 
freeze-drying and the respective factor for converting results per freeze-dried weight (FDW) to fresh weight (FW) was calculated according to the following Formula (1):

$$
\text { Conversion factor }=(b-a) /(c-a)
$$

where $\mathrm{a}=$ weight of empty bottle; $\mathrm{b}=$ weight of the sample with the bottle before freeze-drying; and $c=$ weight of the sample with the bottle after freeze-drying. Details of weight (or moisture) loss due to freeze-drying of the different ILV species are given in Table A1 (Appendix A).

Table 1. Vegetable samples origin and their conversion factors.

\begin{tabular}{|c|c|c|c|c|}
\hline $\begin{array}{c}\text { Sample } \\
\text { Origin-District }\end{array}$ & Botanical Name & Local Names & $\begin{array}{c}\text { Sample } \\
\text { Origin-Village }\end{array}$ & Conversion Factor * \\
\hline \multirow[t]{6}{*}{ Chamwino } & Ceratotheca sesamoides & Ilende & Chinoje & 4.34 \\
\hline & Vigna unguiculata & Safwe & Chinoje & 5.73 \\
\hline & Cleome gynandra & Mzimwe & Mzula & 6.97 \\
\hline & Cleome hirta & Mhilile & Mzula & 7.46 \\
\hline & Ipomoea obscura & Sagula sagula & Mzula & 11.55 \\
\hline & Ipomoea pandurata & Chiwandagulu & Mzula & 8.54 \\
\hline \multirow[t]{7}{*}{ Kilosa } & Bidens pilosa & Mashona nguo & Mhenda & 6.42 \\
\hline & Justicia heterocarpa & Mwidu & Mhenda & 5.22 \\
\hline & Sesamum angustifolium & Mlenda ufuta & Mhenda & 3.99 \\
\hline & Amaranthus spinosus & Mchicha chawa & Tindiga & 6.56 \\
\hline & Amaranthus spp. & Mchicha bwasi & Tindiga & 2.42 \\
\hline & Corchorus trilocularis & Mlenda mgunda & Tindiga & 5.65 \\
\hline & Sonchus luxurians & Sunga & Tindiga & 8.19 \\
\hline
\end{tabular}

\subsection{Analytical Methods}

All determinations were done in freeze-dried samples (powder). Carotenoids, tocopherols, and ascorbic acid (AA) were analysed using High-Performance Liquid Chromatography (HPLC). The minerals iron, calcium, magnesium, zinc, and phosphorus were determined using Inductively Coupled Plasma-Optical Emission Spectrophotometry (ICP-OES), while phytic acid content was analysed after clean-up using a photometric method. Micronutrient and phytate contents in homogenized freeze-dried ILV samples were determined as milligrams per $100 \mathrm{~g}$ dry matter $(\mathrm{mg} / 100 \mathrm{~g})$ and finally converted and presented per fresh weight using the dry-to-fresh conversion factor (Table 1). The conversion from freeze-dried weight to fresh weight was calculated according to the following Formula (2):

Values per fresh weight $=($ Values per freeze - dried weight $) /$ Conversion factor

where (values per freeze - dried weight) are the concentrations per $100 \mathrm{~g}$ freeze-dried weight of respective micronutrients and phytic acid content measured by the HPLC, ICP-OES, and photometric method. Finally, all results (in the tables) are given in $\mathrm{mg}$ or $\mu \mathrm{g} / 100 \mathrm{~g}$ of estimated fresh weight.

\subsubsection{Determination of Carotenoids and Tocopherols}

Carotenoids and tocopherols were extracted and analysed via HPLC, as previously described by Stuetz et al. [14]. Briefly, $100 \mathrm{mg}$ of freeze-dried ILV samples were saponified in screw-capped glass tubes under stirring in a light protected water bath $\left(2.5 \mathrm{~h}\right.$, at $\left.38^{\circ} \mathrm{C}\right)$ by adding $500 \mu \mathrm{L}$ of $\mathrm{KOH}$ $(50 \% w / w)$, and $1 \mathrm{~mL}$ ethanol containing $\beta$-apo- $8^{\prime}$-carotenal methyloxime $(1 \mu \mathrm{L} / \mathrm{mL})$ as an internal standard. After saponification, $2 \mathrm{~mL}$ of saline solution $(15 \% w / V)$ was added, then samples were neutralised with $500 \mu \mathrm{L}$ of glacial acetic acid. The fat-soluble components were extracted with hexane $(2 \times 1 \mathrm{~mL})$, and combined fractions were evaporated in a rotational vacuum evaporator (RVC 2-33 IR, Christ, Osterode am Harz, Germany). The residue was redissolved in $70 \mu \mathrm{L}$ ethanol ( $>96 \%)$ and 
$210 \mu \mathrm{L}$ acetonitrile in order to be analyzed using RP-HPLC, UV-vis (450 $\mathrm{nm}$ for carotenoids) and fluorescence detection (Excitation set at $298 \mathrm{~nm}$ and Emission set at $328 \mathrm{~nm}$ for $\alpha$ - $/ \gamma$-tocopherol). All reagents and solvents were of analytical and (ultra) gradient HPLC grade. N-hexane, 1, 4-dioxane, potassium hydroxide solution (50\%), acetic acid (100\%), and ethanol were from Carl Roth $\mathrm{GmbH}$ + Co. KG (Karlsruhe, Germany), while methanol and acetonitrile were from J.T. Baker (Deventer, The Netherlands).

Recommended daily safe intake of $500 \mu \mathrm{g}$ retinol equivalents (RE) for vitamin A intake and daily acceptable intakes of $7.5 \mathrm{mg}$ of $\alpha$-tocopherol equivalents ( $\alpha$-TE) for vitamin $\mathrm{E}$ intake among females aged 19-50 years were used to estimate the contribution of ILVs [15]. Conversion factors of 12:1 for $\beta$-carotene and 24:1 for other $\beta$-cryptoxanthin and $\alpha$-carotene were applied for the calculation of RE, while $\alpha$-TE were calculated using conversion factors of 1:1 for $\alpha$-tocopherol and 10:1 for $\gamma$-tocopherol [15].

\subsubsection{Determination of Ascorbic Acid (AA)}

Ascorbic acid in $25 \mathrm{mg}$ of freeze-dried samples were extracted with a mixture of $550 \mu \mathrm{L}$ of freshly prepared $10 \%(w / w)$ meta-phosphoric acid (MPA) and $50 \mu \mathrm{L}$ of $20 \%(w / w)$ tris-(2-carboxyethyl)-phosphine (TCEP, $\left.\mathrm{C}_{9} \mathrm{H}_{15} \mathrm{O}_{6} \mathrm{P} \cdot \mathrm{HCl}\right)$ solution as the reduction agent; samples were incubated for $5 \mathrm{~min}$ on ice (in the dark, protected from light), then vortex-mixed for $3 \mathrm{~min}$, and centrifuged at $17,000 \times g$ for $10 \mathrm{~min} ; 20 \mu \mathrm{L}$ of supernatants were analysed on AA content using a Shimadzu Prominence HPLC, a Reprosil-Pur 120 C18 AQ analytical column $(5 \mu \mathrm{m}, 250 \times 4.6 \mathrm{~mm}$, Dr. Maisch $\mathrm{GmbH}$, Ammerbuch, Germany), sodium dihydrogen-phosphate buffer $\left(0.1 \mathrm{M} \mathrm{NaH}_{2} \mathrm{PO}_{4} \mathrm{x}\right.$ $3 \mathrm{H}_{2} \mathrm{O}$, set to $\mathrm{pH} 2.5$ ) as a mobile phase at a flow rate of $1 \mathrm{~mL} / \mathrm{min}$ and an UV-Vis detector (SPD-20A, Shimadzu, Kyoto, Japan) set at $245 \mathrm{~nm}$ [16]. TCEP, MPA, and reagents were from Carl Roth GmbH + Co. KG, Karlsruhe, Germany. The recommended nutrient intake (RNI) was calculated based on $45 \mathrm{mg} /$ day recommendation of Vitamin C for women 19-50 years [15].

\subsubsection{Determination of Minerals}

Iron $(\mathrm{Fe})$, zinc $(\mathrm{Zn})$, calcium $(\mathrm{Ca})$, and magnesium $(\mathrm{Mg})$ contents in $250 \mathrm{mg}$ of samples were determined by ICP-OES after microwave-heated nitric acid digestion using an ultraclave, as previously described [17]. The RNI were calculated based on, iron ( $58.8 \mathrm{mg} /$ day, $5 \%$ bioavailability); zinc ( $9.8 \mathrm{mg} /$ day, low bioavailability); calcium (1000 mg/day) and magnesium (220 mg/day) for women 19-50 years [15].

\subsubsection{Determination of Phytate (and Its Ratio to Analysed Minerals)}

Phytate (inositol hexakisphosphate, IP6) was quantitatively measured by photometry [18] after extraction and clean up using solid-phase extraction (SPE) and anion-exchange purification [19]. In brief, $150 \mathrm{mg}$ of samples were extracted using $0.1 \mathrm{M} \mathrm{HCl}(1.5 \mathrm{~mL})$ and sonication for $30 \mathrm{~min}$. Following samples were centrifuged twice (60 min at 13,300 rpm) and clear supernatants of ILV extracts $(500 \mu \mathrm{L})$ were diluted $(1: 20)$ and adjusted to $\mathrm{pH} 6$ in order to be transferred to SPE glass cartridges filled with $500 \mathrm{mg}$ of anion exchange resin (AG1-X8 resin, Bio-Rad laboratories, Inc., Hercules, CA, USA). Samples were washed ( $0.1 \mathrm{M} \mathrm{NaCl}$ to remove free phosphate) and phytates were eluted with $0.7 \mathrm{M} \mathrm{NaCl}$. Samples were adjusted to $\mathrm{pH} 3$, mixed with Wade reagent $(0.06 \%$ $\mathrm{FeCl}_{3} \cdot 6 \mathrm{H}_{2} \mathrm{O}+0.6 \%$ sulfosalicylic acid) and absorbance was measured at $490 \mathrm{~nm}$. Phytate (phytic acid) standards in concentrations from $25 \mu \mathrm{g} / \mathrm{mL}$ to $200 \mu \mathrm{g} / \mathrm{mL}$ and blanks (Wade reagent) were used for calibration. To predict the bioavailability of calcium, iron and zinc; molar weights (phytate: $660 \mathrm{~g} / \mathrm{mol}$; Ca: $40 \mathrm{~g} / \mathrm{mol}$; Fe: $56 \mathrm{~g} / \mathrm{mol}$; and $\mathrm{Zn}: 65 \mathrm{~g} / \mathrm{mol}$ ) were used to calculate the (molar) ratio of phytate to individual mineral concentrations of the ILVs [20]. 


\subsection{Statistical Analysis}

Results are concentrations per wet weight (fresh weight) and described as means and standard deviations. Data used for provitamin A carotenoids, ascorbic acid and tocopherols were means of triplicate $(n=3)$ determinations while for minerals and phytate were of duplicate $(n=2)$ determinations. Multiple comparisons between ILVs were performed by one-way analysis of variance (ANOVA) and post-hoc Tukey's HSD (Honestly Significant Difference) test; statistical significance was considered at a $p$ value $<0.05$. All statistical analyses were carried out using IBM SPSS software (Version 23, IBM Corp., Armonk, NY, USA).

\section{Results and Discussion}

\subsection{Provitamin A Carotenoids Contents}

The provitamin A carotenoids contents and the contribution of different vegetable species to the RNI of vitamin A (retinol equivalents-RE) are presented in Table 2. Table 2 shows a range of $\beta$-carotene contents between 1.01 and $4.84 \mathrm{mg} / 100 \mathrm{~g}$. Amaranthus spp. (4.84 mg/100 g) had a high $\beta$-carotene content compared to other ILVs. Sesamum angustifolium (4.06 mg/100 g), Corchorus trilocularis $(4.04 \mathrm{mg} / 100 \mathrm{~g})$, and Justicia heterocarpa $(3.84 \mathrm{mg} / 100 \mathrm{~g})$ were also rich in $\beta$-carotene (Table 2). In comparison to other analysed ILVs, Sesamum angustifolium $(0.18 \mathrm{mg} / 100 \mathrm{~g})$ and Justicia heterocarpa $(0.95 \mathrm{mg} / 100 \mathrm{~g})$ had the highest content of $\beta$-cryptoxanthin and $\alpha$-carotene, respectively.

Table 2. Provitamin A carotenoids contents (mg/100 g fresh weight) of ILVs *

\begin{tabular}{|c|c|c|c|c|c|}
\hline Botanical Names & $\beta$-Cryptoxanthin & $\alpha$-Carotene & $\beta$-Carotene & $\mathrm{RE}^{1}(\mu \mathrm{g} / 100 \mathrm{~g})$ & $\%$ of $\mathrm{RNI}^{2}$ \\
\hline Amaranthus spinosus & $0.04 \pm 0.01^{\mathrm{f}, \mathrm{g}}$ & $0.26 \pm 0.01^{b, c}$ & $3.65 \pm 0.17^{a, b, c}$ & $317 \pm 14^{\mathrm{a}, \mathrm{b}, \mathrm{c}}$ & 63 \\
\hline Amaranthus spp. & $0.13 \pm 0.01^{b, c, d}$ & $0.32 \pm 0.01^{b}$ & $4.84 \pm 0.16^{\mathrm{a}}$ & $422 \pm 13^{\mathrm{a}}$ & 84 \\
\hline Bidens pilosa & $0.05 \pm 0.01^{\mathrm{f}, \mathrm{g}}$ & $0.07 \pm 0.01^{\mathrm{c}, \mathrm{d}}$ & $2.07 \pm 0.07^{\mathrm{c}, \mathrm{d}, \mathrm{e}}$ & $178 \pm 6^{\mathrm{c}, \mathrm{d}, \mathrm{e}}$ & 36 \\
\hline Cleome gynandra & $0.13 \pm 0.02^{b, c, d}$ & $0.05 \pm 0.02^{\mathrm{d}}$ & $2.91 \pm 0.41^{b, c, d}$ & $250 \pm 36^{b, c, d}$ & 50 \\
\hline Cleome hirta & $0.06 \pm 0.03^{\mathrm{e}, \mathrm{f}, \mathrm{g}}$ & $0.01 \pm 0.01^{\mathrm{d}}$ & $2.75 \pm 0.20^{b, c, d}$ & $232 \pm 17^{b, c, d}$ & 46 \\
\hline Corchorus trilocularis & $0.11 \pm 0.01^{\mathrm{c}, \mathrm{d}, \mathrm{e}}$ & $0.09 \pm 0.01^{\mathrm{c}, \mathrm{d}}$ & $4.04 \pm 0.57^{\mathrm{a}, \mathrm{b}}$ & $345 \pm 48^{\mathrm{a}, \mathrm{b}}$ & 69 \\
\hline Ceratotheca sesamoides & $0.14 \pm 0.01^{b, c}$ & $0.07 \pm 0.02^{c, d}$ & $1.96 \pm 0.35^{\mathrm{d}, \mathrm{e}}$ & $172 \pm 30^{\mathrm{d}, \mathrm{e}}$ & 34 \\
\hline Ipomoea obscura & $0.09 \pm 0.01^{\mathrm{c}, \mathrm{d}, \mathrm{e}, \mathrm{f}}$ & $0.07 \pm 0.01^{\mathrm{c}, \mathrm{d}}$ & $1.01 \pm 0.04^{\mathrm{e}}$ & $90 \pm 3^{\mathrm{e}}$ & 18 \\
\hline Ipomoea pandurata & $0.05 \pm 0.03^{f, g}$ & $0.16 \pm 0.01^{b, c, d}$ & $2.99 \pm 0.15^{b, c, d}$ & $258 \pm 13^{b, c, d}$ & 52 \\
\hline Justicia heterocarpa & $0.07 \pm 0.01$ e,f,g & $0.95 \pm 0.27^{\mathrm{a}}$ & $3.84 \pm 1.45^{\mathrm{a}, \mathrm{b}}$ & $363 \pm 132^{a, b}$ & 73 \\
\hline Sesamum angustifolium & $0.18 \pm 0.01^{\mathrm{a}, \mathrm{b}}$ & $0.06 \pm 0.01^{\mathrm{c}, \mathrm{d}}$ & $4.06 \pm 0.39^{\mathrm{a}, \mathrm{b}}$ & $349 \pm 33^{a, b}$ & 70 \\
\hline Sonchus luxurians & $0.03 \pm 0.01 \mathrm{~g}$ & $0.03 \pm 0.01^{\mathrm{d}}$ & $2.15 \pm 0.03^{c, d, e}$ & $181 \pm 2^{c, d, e}$ & 36 \\
\hline Vigna unguiculata & $0.08 \pm 0.01^{\mathrm{d}, \mathrm{e}, \mathrm{f}, \mathrm{g}}$ & $0.12 \pm 0.05^{b, c, d}$ & $2.96 \pm 1.26^{\mathrm{b}, \mathrm{c}, \mathrm{d}}$ & $255 \pm 107^{b, c, d}$ & 51 \\
\hline
\end{tabular}

* ILVs, indigenous leafy vegetables: values are means \pm SD; values within a column not sharing a common superscript letter $(\mathrm{a}, \mathrm{b}, \mathrm{c}, \mathrm{d}, \mathrm{e}, \mathrm{f}, \mathrm{g})$ are significantly different (Tukey $\leq 0.05) .{ }^{1} \mathrm{RE}$, retinol equivalents (sum of RE), for which $1 \mathrm{RE}=12 \mu \mathrm{g} \beta$-carotene or $24 \mu \mathrm{g} \alpha$-carotene or $24 \mu \mathrm{g} \beta$-cryptoxanthin. ${ }^{2} \mathrm{RNI}$, recommended nutrient intakes by WHO/FAO [15]; values as (microgram) for female adults (19-50 years).

$\beta$-Carotene contents of Cleome gynandra, Sonchus luxurians, and Amaranthus spp., from this study, were in agreement with other reported values of ILVs in Tanzania [4,21]. Limited results are available for $\beta$-cryptoxanthin and $\alpha$-carotene comparison. A study on ILVs from Cameroon [22], reported contents (per dry weight) of $\beta$-cryptoxanthin $(0.21 \pm 0.03 \mathrm{mg} / 100 \mathrm{~g})$ and $\alpha$-carotene $(0.21 \pm 0.05 \mathrm{mg} / 100 \mathrm{~g})$ in Ceratotheca sesamoides. However, a strong comparison cannot be made between the reported contents and data from the present study, as different drying techniques were used: Sun drying in the previous work versus freeze-drying in the present study.

The stability and retention of carotenoids in food are influenced by various factors including their chemical nature, storage time, storage conditions, cooking, and preparation methods [2,23]. Indigenous leafy vegetables in Tanzania are mostly prepared by steaming, boiling, or stir-frying together with other vegetables such as tomatoes and onions. Steaming and stir-frying with oil are mentioned as desirable methods for preparing ILVs in view of carotenoids retention and bioavailability [2,23,24]. Due to different plant matrices, the bioavailability of carotenoids from orange-pigmented fruits was superior 
to that of dark-green leafy vegetables, as reported by De Pee et al. [25]. However, the bioavailability of $\beta$-carotene and other carotenoids can be enhanced through food processing (cooking, homogenisation) and fat in the diet [26-28]. Moderate cooking and/or mechanical homogenisation, which destroys the cell walls, increase the release of carotenoids, while a sufficient amount of dietary fat (3-5 g per meal), especially if rich in unsaturated fatty acids, is essential for maximal carotenoid absorption from vegetables $[27,28]$. Results in the present study indicate Amaranthus spp., Justicia heterocarpa, Sesamum angustifolium, Corchorus trilocularis, Amaranthus spinosus, Ipomoea pandurata, Vigna unguiculata and Cleome gynandra as rich sources of vitamin A since the consumption of $100 \mathrm{~g}$ of these vegetable species can provide between $50 \%$ to $84 \%$ of the RNI for retinol equivalents (RE). A study conducted in central and North-Eastern parts of Tanzania [29] reported an average per capita vegetable intake of $207 \mathrm{~g}$ per day, suggesting a contribution of 104 to 174 percent of the RNI for retinol equivalents (RE), and thus underlining an important contribution of these ILVs to ensuring vitamin A intake by the population in the study areas.

\subsection{Tocopherols and Ascorbic Acid Contents}

Low contents of $\gamma$ - and $\alpha$-tocopherol were observed in almost all analysed samples; Sesamum angustifolium being the exception with a high concentration of $\alpha$-tocopherol $(7.29 \mathrm{mg} / 100 \mathrm{~g})$ (Table 3). In comparison to other ILVs, Amaranthus spp. exhibited the highest $\gamma$-tocopherol content $(0.67 \mathrm{mg} / 100 \mathrm{~g})$ followed by Sesamum angustifolium $(0.54 \mathrm{mg} / 100 \mathrm{~g})$. A $100 \mathrm{~g}$ portion of Sesamum angustifolium with the highest level of $\alpha$-tocopherol equivalents ( $\alpha$-TEs) could provide $98 \%$ of the acceptable intake for vitamin E (Table 3). This could be explained by the presence of immature seeds that were part of the leaves in the sample; further research and analysis on separated leaves and seeds are required to describe and confirm Sesamum angustifolium as an excellent source for vitamin E. Until now, little information is available on the tocopherol contents of Sesamum angustifolium leaves. One previous study on Sesamum angustifolium seeds [30], reported total tocopherol contents of approximately $760 \mathrm{mg} / \mathrm{kg}$ oil, consisting $\gamma$ - and $\delta$-tocopherol, but no $\alpha$-tocopherol. Studies done on the leaf of the sesame species Sesamum indicum reported the presence of $\alpha$-tocopherol content $(0.55 \mathrm{mg} / 100 \mathrm{~g}$ edible portion) but no detection of $\gamma$-tocopherol [31]. Vitamin $\mathrm{E}$ is the major lipid-soluble antioxidant that provides protection against lipid peroxidation and protects components of cell membranes from oxidation by free radicals, thus preventing or delaying the onset of chronic diseases associated with reactive oxygen species molecules [15,32]. The richest sources of tocopherols include nuts, seeds, and vegetable oils [32]. Results from the present study suggest further research into the contribution of Sesamum angustifolium as a source of tocopherols in the diet.

The ascorbic acid contents of 13 analysed ILVs ranged between $0.08 \mathrm{mg} / 100 \mathrm{~g}$ for Justicia heterocarpa, to $15.6 \mathrm{mg} / 100 \mathrm{~g}$ for Cleome hirta (Table 3). In previous studies a vitamin C content of $2 \mathrm{mg} / 100 \mathrm{~g}$ in Amaranthus spp., $9 \mathrm{mg} / 100 \mathrm{~g}$ in Vigna unguiculata and $2 \mathrm{mg} / 100 \mathrm{~g}$ in Cleome gynandra [3] was reported, which by contrast shows higher contents for Amaranthus spp and Vigna unguiculata but lower for Cleome gynandra (Table 3). Ascorbic acid values for Cleome gynandra are in agreement with that reported in other studies [1,33]. Variations in the contents of ascorbic acid in ILVs are known to be related to various factors such as plant variety or species, maturity stage, storage time and high temperature [33,34]. Vitamin C is a water-soluble antioxidant required for normal metabolic functions of the body and plays an important role as an enhancer of dietary $\mathrm{Fe}$ absorption $[35,36]$. Since non-heme Fe is the only Fe compound in plants, its absorption is said to be improved by dietary constituents such as ascorbic acid and other organic acids [37]. Five of the analysed ILVs could contribute more than $10 \%$ of the RNI by $100 \mathrm{~g}$ fresh weight, with Cleome hirta and Cleome gynandra reaching 35\% and 34\% of the RNI, and thus the reported average per capita vegetable intake of $207 \mathrm{~g}$ per day [29], would provide between 71 and 72 percent of the RNI for vitamin $C$ (Table 3). Since longer storage times and higher temperatures reduce the ascorbic acid contents, a significant ascorbic acid supply through Cleome hirta and Cleome gynandra can only be achieved when these leaves are utilized immediately after harvesting. Additionally, shorter cooking times, with low 
water content, as well as the consumption of the cooking water are also recommended as measures to ensure ascorbic acid retention and intake [38].

Table 3. Tocopherols and ascorbic acid contents (mg/100 $\mathrm{g}$ fresh weight) in ILVs *.

\begin{tabular}{|c|c|c|c|c|c|c|}
\hline Botanical Names & $\gamma$-Tocopherol & $\alpha$-Tocopherol & $\alpha-\mathrm{TE}^{1}$ & $\% \mathrm{AI}^{2}$ & Ascorbic Acid & $\% \mathrm{RNI}^{3}$ \\
\hline Amaranthus spinosus & $0.01 \pm 0.01^{\mathrm{c}}$ & $0.01 \pm 0.01^{b}$ & $0.01 \pm 0.01^{b}$ & 0 & $0.30 \pm 0.02 \mathrm{~g}$ & 1 \\
\hline Amaranthus spp. & $0.67 \pm 0.05^{\mathrm{a}}$ & $0.01 \pm 0.01^{\mathrm{b}}$ & $0.07 \pm 0.01^{b}$ & 1 & $0.48 \pm 0.01^{\mathrm{f}, \mathrm{g}}$ & 1 \\
\hline Bidens pilosa & $0.02 \pm 0.01^{\mathrm{c}}$ & $0.03 \pm 0.02^{b}$ & $0.03 \pm 0.02^{b}$ & 0 & $1.20 \pm 0.05^{\mathrm{f}, \mathrm{g}}$ & 3 \\
\hline Cleome gynandra & $0.01 \pm 0.01^{\mathrm{c}}$ & $0.02 \pm 0.01^{\mathrm{b}}$ & $0.02 \pm 0.01^{b}$ & 0 & $15.44 \pm 0.91^{\mathrm{a}}$ & 34 \\
\hline Cleome hirta & $0.01 \pm 0.01^{\mathrm{c}}$ & $0.01 \pm 0.01^{b}$ & $0.01 \pm 0.01^{\mathrm{b}}$ & 0 & $15.60 \pm 0.24^{\mathrm{a}}$ & 35 \\
\hline Corchorus trilocularis & $0.04 \pm 0.06^{c}$ & $0.04 \pm 0.03^{b}$ & $0.04 \pm 0.04^{b}$ & 1 & $0.25 \pm 0.01^{g}$ & 1 \\
\hline Ceratotheca sesamoides & $0.02 \pm 0.01^{\mathrm{c}}$ & $0.03 \pm 0.01^{b}$ & $0.03 \pm 0.01^{b}$ & 0 & $6.48 \pm 0.07^{\mathrm{d}}$ & 14 \\
\hline Ipomoea obscura & $0.01 \pm 0.01^{\mathrm{c}}$ & $0.01 \pm 0.01^{\mathrm{b}}$ & $0.01 \pm 0.01^{b}$ & 0 & $1.60 \pm 0.15^{\mathrm{f}}$ & 4 \\
\hline Ipomoea pandurata & $0.04 \pm 0.01^{c}$ & $0.07 \pm 0.01^{b}$ & $0.07 \pm 0.01^{\mathrm{b}}$ & 1 & $11.28 \pm 0.13^{b}$ & 25 \\
\hline Justicia heterocarpa & $0.03 \pm 0.01^{\mathrm{c}}$ & $0.02 \pm 0.01^{b}$ & $0.02 \pm 0.01^{b}$ & 0 & $0.08 \pm 0.01^{g}$ & 0 \\
\hline Sesamum angustifolium & $0.54 \pm 0.06^{\mathrm{b}}$ & $7.29 \pm 0.75^{\mathrm{a}}$ & $7.34 \pm 0.75^{a}$ & 98 & $4.09 \pm 0.22^{\mathrm{e}}$ & 9 \\
\hline Sonchus luxurians & $0.01 \pm 0.01^{c}$ & $0.01 \pm 0.01^{b}$ & $0.01 \pm 0.01^{\mathrm{b}}$ & 0 & $0.68 \pm 0.03^{\mathrm{f}, \mathrm{g}}$ & 2 \\
\hline Vigna unguiculata & $0.04 \pm 0.01^{c}$ & $0.02 \pm 0.01^{b}$ & $0.02 \pm 0.01^{b}$ & 0 & $8.96 \pm 0.01^{c}$ & 20 \\
\hline
\end{tabular}

* ILVs, indigenous leafy vegetables: values are means \pm SD; values within a column not sharing a common superscript letter $(\mathrm{a}, \mathrm{b}, \mathrm{c}, \mathrm{d}, \mathrm{e}, \mathrm{f}, \mathrm{g})$ are significantly different (Tukey $\leq 0.05) .{ }^{1} \alpha$-TEs, $\alpha$-tocopherol equivalents $(1 \mathrm{mg}$ $\alpha$-TE $=1 \mathrm{mg} \alpha$-tocopherol or $10 \mathrm{mg} \gamma$-tocopherol). ${ }^{2} \mathrm{AI}$, acceptable intake [15]. ${ }^{3} \mathrm{RNI}$, recommended nutrient intakes by WHO/FAO [15]; values in (milligram) for female adults (19-50 years).

\subsection{Mineral Contents}

The mean values of the vegetable mineral contents and their contribution to the RNI are presented in Tables 4 and 5. Considerable amounts of Fe $(2.4-60.4 \mathrm{mg} / 100 \mathrm{~g}) \mathrm{Zn}(0.37-2.05 \mathrm{mg} / 100 \mathrm{~g})$, Ca $(100-853.7 \mathrm{mg} / 100 \mathrm{~g})$, and $\mathrm{Mg}(37.7-455.8 \mathrm{mg} / 100 \mathrm{~g})$ were found in the analysed ILV species. The ILVs with highest Fe contents were Amaranthus spp. (60.4 mg/100 g), Cleome hirta (56.4 mg/100 g), Corchorus trilocularis $(43.5 \mathrm{mg} / 100 \mathrm{~g})$, Sonchus luxurians $(42.2 \mathrm{mg} / 100 \mathrm{~g})$, Cleome gynandra $(39.0 \mathrm{mg} / 100 \mathrm{~g})$, and Ceratotheca sesamoides (34.5 mg/100 g). Amaranthus spp. also contained the highest amount of $\mathrm{Zn}(2.05 \mathrm{mg} / 100 \mathrm{~g})$ in comparison to other ILVs (Table 4). Previous studies in Tanzania [4,39] reported Fe and Zn contents in Amaranthus spp., Bidens pilosa, Sonchus luxurians, Chorchorus trilocularis, and Vigna unguiculata in agreement with the ones in the present study. In a review on Bidens pilosa [2], Fe contents ranging between 2.0 to $6.0 \mathrm{mg} / 100 \mathrm{~g}$ fresh weight, $\mathrm{Zn}$ between 0.9 to $2.6 \mathrm{mg} / 100 \mathrm{~g}$ fresh weight, and Ca between 162 to $340 \mathrm{mg} / 100 \mathrm{~g}$ fresh weight were similar with contents reported in the present study. Other researchers $[1,40,41]$, however, reported lower Fe concentrations (2.48-14.4 mg/100) in Bidens pilosa, Cleome gynandra, Amaranthus spinosus, and Corchorus trilocularis compared to those reported in the present study. The $\mathrm{Zn}$ content for Bidens pilosa was in agreement with the one reported by Reference [41].

Iron plays numerous biochemical roles in the body including the formation of red blood cells [9]. Limited supply of Fe in most usual African diets is due to low intake of animal-based foods [42]. ILVs such as Amaranthus spp., Cleome hirta, Corchorus trilocularis and Sonchus luxurians with high Fe content which could contribute $103 \%, 96 \%, 74 \%$, and $72 \%$ to the RNI per $100 \mathrm{~g}$, respectively, can be recommended to alleviate iron deficiency anaemia in communities with limited access to animal food sources.

Zinc is important in gastrointestinal and immune functions, energy metabolism and as a co-enzyme in numerous biochemical reactions in the body [2,9]. Low contents of $\mathrm{Zn}$ were recorded in most of the analysed ILVs (Table 4). In comparison to other analysed ILV species, Amaranthus spp. had a high Zn content (2.05 mg/100 g), which could contribute to $21 \%$ to the RNI (Table 4). Similar results were reported in studies conducted in South Africa on Amaranthus spinosus, Bidens pilosa, Cleome gynandra, and Vigna unguiculata [3,41]. Overall, these results show that the analysed ILVs can contribute to a lesser extent to $\mathrm{Zn}$ nutrition in comparison to Fe. 
Table 4. Iron and zinc contents (mg/100 $\mathrm{g}$ fresh weight) of ILVs *.

\begin{tabular}{ccccc}
\hline Botanical Names & Iron & \% of RNI $^{\mathbf{1}}$ & Zinc $^{\text {on }}$ & \% of RNI $^{\mathbf{1}}$ \\
\hline Amaranthus spinosus & $19.8 \pm 1.7^{\mathrm{d}}$ & 34 & $0.82 \pm 0.01^{\mathrm{b}}$ & 8 \\
Amaranthus spp. & $60.4 \pm 3.6^{\mathrm{a}}$ & 103 & $2.05 \pm 0.01^{\mathrm{a}}$ & 21 \\
Bidens pilosa & $3.3 \pm 0.2^{\mathrm{g}}$ & 6 & $0.86 \pm 0.01^{\mathrm{b}}$ & 9 \\
Cleome gynandra & $39.0 \pm 2.7^{\mathrm{b}, \mathrm{c}}$ & 66 & $0.46 \pm 0.01^{\mathrm{e}}$ & 5 \\
Cleome hirta & $56.4 \pm 2.5^{\mathrm{a}}$ & 96 & $0.46 \pm 0.01^{\mathrm{e}}$ & 5 \\
Corchorus trilocularis & $43.5 \pm 1.1^{\mathrm{b}}$ & 74 & $0.46 \pm 0.01^{\mathrm{e}}$ & 5 \\
Ceratotheca sesamoides & $34.5 \pm 0.7^{\mathrm{c}}$ & 59 & $0.67 \pm 0.01^{\mathrm{d}}$ & 7 \\
Ipomoea obscura & $19.6 \pm 0.4^{\mathrm{d}}$ & 33 & $0.38 \pm 0.01^{\mathrm{f}}$ & 4 \\
Ipomoea pandurata & $10.3 \pm 0.0^{\mathrm{e}, \mathrm{f}}$ & 18 & $0.37 \pm 0.02^{\mathrm{f}}$ & 4 \\
Justicia heterocarpa & $10.5 \pm 0.5^{\mathrm{e}, \mathrm{f}}$ & 18 & $0.75 \pm 0.04^{\mathrm{c}}$ & 8 \\
Sesamum angustifolium & $2.4 \pm 0.3^{\mathrm{g}}$ & 4 & $0.72 \pm 0.01^{\mathrm{c}}$ & 7 \\
Sonchus luxurians & $42.2 \pm 0.7^{\mathrm{b}}$ & 72 & $0.40 \pm 0.01^{\mathrm{f}}$ & 4 \\
Vigna unguiculata & $5.1 \pm 0.1^{\mathrm{f}, \mathrm{g}}$ & 9 & $0.41 \pm 0.01^{\mathrm{f}}$ & 4 \\
\hline
\end{tabular}

* ILVs, indigenous leafy vegetables: values are means \pm SD; values within a column not sharing a common superscript letter $(\mathrm{a}, \mathrm{b}, \mathrm{c}, \mathrm{d}, \mathrm{e}, \mathrm{f}, \mathrm{g})$ are significantly different (Tukey $\leq 0.05) .{ }^{1} \mathrm{RNI}$, recommended nutrient intakes by $\mathrm{WHO} / \mathrm{FAO}[15]$; values as (milligram) for female adults (19-50 years).

Table 5. Calcium and magnesium (mg/100 g fresh weight) of ILVs *.

\begin{tabular}{ccccc}
\hline Botanical Names & Calcium & \% of RNI $^{\mathbf{1}}$ & Magnesium & \% of RNI $^{\mathbf{1}}$ \\
\hline Amaranthus spinosus & $289.1 \pm 9.2^{\mathrm{c}, \mathrm{d}}$ & 29 & $202.9 \pm 0.3^{\mathrm{b}}$ & 92 \\
Amaranthus spp. & $853.7 \pm 24.9^{\mathrm{a}}$ & 85 & $455.8^{\mathrm{a}} \pm 0.1^{\mathrm{a}}$ & 207 \\
Bidens pilosa & $163.1 \pm 1.1^{\mathrm{g}, \mathrm{h}}$ & 16 & $60.0 \pm 0.2^{\mathrm{i}}$ & 27 \\
Cleome gynandra & $260.1 \pm 2.8^{\mathrm{d}, \mathrm{e}}$ & 26 & $70.1 \pm 0.1^{\mathrm{fg}}$ & 32 \\
Cleome hirta & $310.5^{\mathrm{a}} \pm 1.3^{\mathrm{c}}$ & 31 & $44.8 \pm 0.0^{\mathrm{j}}$ & 20 \\
Corchorus trilocularis & $167.3 \pm 2.9^{\mathrm{g}}$ & 17 & $62.0 \pm 0.4^{\mathrm{i}}$ & 28 \\
Ceratotheca sesamoides & $248.8 \pm 3.1^{\mathrm{e}, \mathrm{f}}$ & 25 & $129.4 \pm 1.8^{\mathrm{c}}$ & 59 \\
Ipomoea obscura & $100.0 \pm 1.7^{\mathrm{i}}$ & 10 & $37.7 \pm 0.5^{1}$ & 17 \\
Ipomoea pandurata & $143.3 \pm 1.0^{\mathrm{g}, \mathrm{h}}$ & 14 & $67.2 \pm 0.6^{\mathrm{h}}$ & 31 \\
Justicia heterocarpa & $478.6 \pm 3.3^{\mathrm{b}}$ & 48 & $79.7 \pm 0.1^{\mathrm{e}}$ & 36 \\
Sesamum angustifolium & $168.4 \pm 5.1^{\mathrm{g}}$ & 17 & $83.7 \pm 1.4^{\mathrm{d}}$ & 38 \\
Sonchus luxurians & $135.3 \pm 1.2^{\mathrm{h}}$ & 14 & $41.1 \pm 0.3^{\mathrm{k}}$ & 19 \\
Vigna unguiculata & $274.2 \pm 4.4^{\mathrm{d}, \mathrm{e}}$ & 27 & $70.8 \pm 1.0^{\mathrm{f}}$ & 32 \\
\hline
\end{tabular}

* ILVs, indigenous leafy vegetables: values are means \pm SD; values within a column not sharing a common superscript letter $(\mathrm{a}, \mathrm{b}, \mathrm{c}, \mathrm{d}, \mathrm{e}, \mathrm{f}, \mathrm{g}, \mathrm{h}, \mathrm{i}, \mathrm{j}, \mathrm{k}, \mathrm{l})$ are significantly different (Tukey $\leq 0.05) .{ }^{1} \mathrm{RNI}$, recommended nutrient intakes by $\mathrm{WHO} / \mathrm{FAO}$ [15]; values as (milligram) for female adults (19-50 years).

The range of Ca in the ILVs was between $100 \mathrm{mg} / 100 \mathrm{~g}$ in Ipomoea obscura and $853.7 \mathrm{mg} / 100 \mathrm{~g}$ Amaranthus spp., while for $\mathrm{Mg}$ it was between $37.7 \mathrm{mg} / 100 \mathrm{~g}$ in Ipomoea obscura and $455.8 \mathrm{mg} / 100 \mathrm{~g}$ in Amaranthus spp. (Table 5). The Ca content was higher in Amaranthus spp., followed by Justicia heterocarpa: an estimated consumption of $100 \mathrm{~g}$ could contribute $85 \%$ (Amaranthus spp.) and $48 \%$ (Justicia heterocarpa) of the RNI for Ca. In comparison to other analysed ILVs, the Mg content in Amaranthus spp. (455.8 mg/100 g), and Amaranthus spinosus (202.9 mg/100 g) was high, contributing a possible $207 \%$ and $92 \%$ of the RNI, respectively. Ca contents of Bidens pilosa and Cleome gynandra were in similar ranges of those reported by $[3,41]$. The values of magnesium in Amaranthus spinosus and Cleome gynandra were in agreement with the ones reported by [41]. Ca and Mg play important roles in development and maintenance of healthy bones and muscles [9]. A $100 \mathrm{~g}$ portion of the analysed ILVs did not meet the RNI for calcium but Amaranthus spp. and Justicia heterocarpa can be regarded as valuable Ca sources with possible contributions of $85 \%$ and $48 \%$ to the RNI (Table 5). Amaranthus spp. was the ILV with a high Mg content, reaching 2-fold the RNI per $100 \mathrm{~g}$ fresh weight. The bioavailability of $\mathrm{Ca}$ and $\mathrm{Mg}$ is dependent on the age and sex of an individual, fat content in the diet and the presence of antinutrients [2]. Therefore, Amaranthus spp., Amaranthus spinosus, and Ceratotheca sesamoides could 
potentially contribute towards the dietary requirements of these two minerals when cooking methods such as boiling, steaming, and stir-frying with oil are applied [7,9,24,43].

The quantitative analysis on minerals in ILVs revealed considerable high contents of $\mathrm{Fe}, \mathrm{Ca}$, and $\mathrm{Mg}$ in certain ILV species and therefore an important contribution to recommended daily mineral intakes. Most notable are the high concentrations of $\mathrm{Fe}, \mathrm{Ca}$ and $\mathrm{Mg}$ in Amaranthus spp. compared to other ILVs. Cleome gynandra and Cleome hirta could serve as important ILVs in iron nutrition due to their appreciable contents of ascorbic acid that enhances Fe absorption. By contrast, the analysed ILVs could not serve as very good sources of $Z n$, since only $21 \%$ of the RNI was reached by the highest $\mathrm{Zn}$ content in Amaranthus spp. (Table 5). However, in comparison to the $\mathrm{Zn}$ contents of boiled rice $(0.5 \mathrm{mg} / 100 \mathrm{~g})$ and maize stiff porridge $(0.6 \mathrm{mg} / 100 \mathrm{~g})$, which are important staple dishes in Tanzania [44], Amaranthus spp. has more zinc content and this suggests that its integration could improve $\mathrm{Zn}$ content in the consumed diets.

\subsection{Phytate Content}

The phytate contents and molar ratios along with the suggested critical values for estimating the effect of phytate on the bioavailability of $\mathrm{Fe}, \mathrm{Zn}$, and Ca are presented in Table 6. Amaranthus spp. (739 mg/100 g) and Amaranthus spinosus (334 mg/100 g) had the highest phytate contents compared to other ILVs (Table 6). The calculated phytate: Iron molar ratios for six ILV samples (Table 6) were above the suggested critical level $(>1)$ indicating poor iron bioavailability $[45,46]$. In this context, Cleome gynandra, Cleome hirta, Corchorus trilocularis, Sonchus luxurians, and Ceratotheca sesamoides with phytate:iron molar ratio $<1$ are better sources of bioavailable iron (Table 6). The phytate: zinc molar ratios of Ceratotheca sesamoides, Sonchus luxurians, Bidens pilosa, Cleome hirta and Justicia heterocarpa were below the suggested critical level of 15 , above which zinc bioavailability is seriously impaired [46]. Amaranthus spp. had high contents of $\mathrm{Ca}, \mathrm{Fe}$, and $\mathrm{Zn}$ (Tables 4-6), a low phytate:calcium (0.05), a still acceptable phytate:iron (1.04), but an unfortunately high phytate:zinc molar ratio (35.71). However, in consideration of the applied RNI for low zinc and 5\% iron bioavailability, Amaranthus spp. can serve as an important source of $\mathrm{Fe}$ and $\mathrm{Zn}$ in the diet. The phytate: Calcium molar ratios in all the leafy vegetable samples ranged between $0.01-0.07$, which is well below the critical level of 0.24 , above which it is said that calcium bioavailability is impaired [46]. This suggests that the phytate contents of the analysed ILVs will not have a substantial impact on the calcium bioavailability.

Table 6. Phytate (mg/100 g fresh weight) and its ratios to minerals in ILVs *.

\begin{tabular}{ccccc}
\hline Botanical Names & Phytate $^{\mathbf{1}}$ & Phytate:iron $^{\text {Phytate:zinc }}$ & Phytate:calcium \\
\hline Amaranthus spinosus & $334 \pm 61^{\mathrm{b}}$ & 1.43 & 40.35 & 0.07 \\
Amaranthus spp. & $739 \pm 74^{\mathrm{a}}$ & 1.04 & 35.71 & 0.05 \\
Bidens pilosa & $119 \pm 21^{\mathrm{c}}$ & 3.06 & 13.71 & 0.04 \\
Cleome gynandra & $120 \pm 6^{\mathrm{c}}$ & 0.26 & 25.84 & 0.03 \\
Cleome hirta & $55 \pm 16^{\mathrm{c}}$ & 0.08 & 11.84 & 0.01 \\
Corchorus trilocularis & $158 \pm 3^{\mathrm{c}}$ & 0.31 & 34.02 & 0.06 \\
Ceratotheca sesamoides & $57 \pm 28^{\mathrm{c}}$ & 0.14 & 8.43 & 0.01 \\
Ipomoea obscura & $68 \pm 18^{\mathrm{c}}$ & 0.29 & 17.73 & 0.04 \\
Ipomoea pandurata & $104 \pm 27^{\mathrm{c}}$ & 0.86 & 27.84 & 0.04 \\
Justicia heterocarpa & $103 \pm 8^{\mathrm{c}}$ & 0.83 & 13.60 & 0.01 \\
Sesamum angustifolium & $146 \pm 30^{\mathrm{c}}$ & 5.16 & 20.09 & 0.05 \\
Sonchus luxurians & $44 \pm 11^{\mathrm{c}}$ & 0.09 & 10.90 & 0.02 \\
Vigna unguiculata & $109 \pm 26^{\mathrm{c}}$ & 1.81 & 26.33 & 0.02 \\
\hline
\end{tabular}

* ILVs, indigenous leafy vegetables: ${ }^{1}$ values are means \pm SD; values within a column not sharing a common superscript letter $(\mathrm{a}, \mathrm{b}, \mathrm{c})$ are significantly different (Tukey $\leq 0.05)$; Critical values of molar ratios predicting the inhibitory effect of phytate on $\mathrm{Fe}, \mathrm{Zn}$, and Ca: phytate:iron $>1$, phytate:zinc $>15$, phytate:calcium $>0.24$ [46].

Phytate, which is the major storage form of phosphorus in plants [2] has the ability to form chelates with di-and tri-valent metallic ions such as $\mathrm{Zn}, \mathrm{Fe}, \mathrm{Mg}$, and $\mathrm{Ca}$ to form poorly soluble compounds 
that are not readily absorbed from the gastrointestinal tract, thus decreasing their bioavailability [47]. Previous studies reported that traditional food preparation and cooking methods (fermentation, boiling, or frying) can significantly reduce phytate content in vegetables $[7,9,10,43]$. Therefore, the diminishing effect on phytate content by suggested cooking methods can even increase the contribution of ILVs as important sources of $\mathrm{Fe}, \mathrm{Zn}$, and $\mathrm{Ca}$.

\section{Conclusions}

The analysed indigenous leafy vegetables (ILVs) contain substantial amount of provitamin A carotenoids, minerals, but also the anti-nutritional factor phytate. There are differences in concentrations of essential micronutrients between ILV species and thus diverse consumption is beneficial in terms of micronutrient supply. The remarkable contents of iron and $\beta$-carotene revealed in the ILVs can serve an important role to safeguard iron and vitamin A supply in the study area. In rural settings where households rely on the consumption of ILVs improved preparation and processing methods to ensure carotenoids retention and reduction of phytate would be further measures to ensure vitamin A and iron supply in the population.

Author Contributions: V.F.G. conducted sample collection, carried out laboratory and data analysis and drafted the manuscript. C.K. and W.S. supported laboratory analysis. J.K., T.J., C.K., J.F. and W.S., provided significant advice and critically edited the manuscript.

Acknowledgments: This study was done under the project Scaling Up nutrition (Scale-N) funded by the German Federal Ministry of Food and Agriculture (BMEL) based on the decision of the Parliament of the Federal Republic of Germany through the Federal Office for Agriculture and Food (BLE). This financial support and the cooperation of village leaders and community members during the sample collection in the study areas are highly acknowledged. We also thank Johanita Kruger for proofreading the manuscript.

Conflicts of Interest: The authors declare no conflict of interest.

\section{Appendix A}

Table A1. Weights of ILVs before and after freeze drying in grams *.

\begin{tabular}{ccccc}
\hline Botanical Names & $\begin{array}{c}\text { Fresh Weight } \\
\text { (gram) }\end{array}$ & $\begin{array}{c}\text { Dried Weight } \\
\text { (gram) }\end{array}$ & $\begin{array}{c}\text { Moisture Loss } \\
\text { (gram) }\end{array}$ & $\begin{array}{c}\text { Moisture Loss } \\
\text { ( }\end{array}$ \\
\hline Amaranthus spinosus & 10.048 & 1.531 & 8.517 & 84.76 \\
Amaranthus spp. & 38.660 & 15.99 & 22.67 & 58.64 \\
Bidens pilosa & 10.216 & 1.591 & 8.625 & 84.43 \\
Cleome gynandra & 45.380 & 6.510 & 38.87 & 85.65 \\
Cleome hirta & 68.430 & 9.170 & 59.26 & 86.60 \\
Corchorus trilocularis & 12.744 & 2.257 & 10.487 & 82.29 \\
Ceratotheca sesamoides & 205.99 & 47.47 & 158.52 & 76.96 \\
Ipomoea obscura & 86.380 & 7.480 & 78.900 & 91.34 \\
Ipomoea pandurata & 166.59 & 19.50 & 147.09 & 88.29 \\
Justicia heterocarpa & 12.937 & 2.479 & 10.458 & 80.84 \\
Sesamum angustifolium & 9.179 & 2.298 & 6.881 & 74.96 \\
Sonchus luxurians & 11.903 & 1.453 & 10.450 & 87.79 \\
Vigna unguiculata & 207.39 & 36.21 & 171.18 & 82.54 \\
\hline
\end{tabular}

${ }^{*}$ ILVs, indigenous leafy vegetables: ${ }^{1}$ Fresh weight $=$ weight before freeze drying; ${ }^{2}$ Dried weight $=$ weight after freeze drying; ${ }^{3}$ Moisture loss $=$ fresh weight - dried weight; ${ }^{4}$ Moisture loss $=$ Moisture loss $/$ Fresh weight $\times 100$.

\section{References}

1. Amagloh, F.K.; Atuna, R.A.; McBride, R.; Carey, E.E.; Christides, T. Nutrient and total polyphenol contents of dark green leafy vegetables, and estimation of their iron bioaccessibility using the in vitro digestion/Caco-2 cell model. Foods 2017, 6, 54. [CrossRef] [PubMed] 
2. Uusiku, N.P.; Oelofse, A.; Duodu, K.G.; Bester, M.J.; Faber, M. Nutritional value of leafy vegetables of sub-Saharan Africa and their potential contribution to human health: A review. J. Food Compos. Anal. 2010, 23, 499-509. [CrossRef]

3. Van Jaarsveld, P.; Faber, M.; Van Heerden, I.; Wenhold, F.; van Rensburg, W.J.; Van Averbeke, W. Nutrient content of eight African leafy vegetables and their potential contribution to dietary reference intakes. J. Food Compos. Anal. 2014, 33, 77-84. [CrossRef]

4. Weinberger, K.; Msuya, J. Indigenous Vegetables in Tanzania: Significance and Prospects; Technical Bulletin No. 31; AVRDC-World Vegetable Center: Tainan, Taiwan, 2004; Volume 04.

5. Masarirambi, M.; Mavuso, V.; Songwe, V.; Nkambule, T. Indigenous post-harvest handling and processing of traditional vegetables in Swaziland: A review. Afr. J. Agric. Res. 2010, 5, 3333-3341.

6. Maroyi, A. Use of weeds as traditional vegetables in Shurugwi District, Zimbabwe. J. Ethnobiol. Ethnomed. 2013, 9, 60. [CrossRef]

7. Essack, H.; Odhav, B.; Mellem, J.J. Screening of traditional South African leafy vegetables for specific anti-nutritional factors before and after processing. Food Sci. Technol. 2017, 37, 462-471. [CrossRef]

8. Kruger, J.; Mongwaketse, T.; Faber, M.; Van der Hoeven, M.; Smuts, C.M. Potential contribution of African green leafy vegetables and maize porridge composite meals to iron and zinc nutrition. Nutrition 2015, 31, 1117-1123. [CrossRef]

9. Patricia, O.; Zoue, L.; Megnanou, R.-M.; Doue, R.; Niamke, S. Proximate composition and nutritive value of leafy vegetables consumed in Northern Côte d'Ivoire. Eur. Sci. J. ESJ 2014, 10, 212-217.

10. Hailu, A.A.; Addis, G. The content and bioavailability of mineral nutrients of selected wild and traditional edible plants as affected by household preparation methods practiced by local community in Benishangul Gumuz Regional State, Ethiopia. Int. J. Food Sci. 2016, 2016. [CrossRef]

11. Shekhar, C. Hidden hunger: Addressing micronutrient deficiencies using improved crop varieties. Chem. Biol. 2013, 20, 1305-1306. [CrossRef] [PubMed]

12. National Bureau of Statistics Tanzania; ICF Macro. Micronutrients: Results of the 2010 Tanzania Demographic and Health Survey; ICF Macro: Calverton, MD, USA, 2011.

13. Graef, F.; Uckert, G.; Schindler, J.; König, H.J.; Mbwana, H.A.; Fasse, A.; Mwinuka, L.; Mahoo, H.; Kaburire, L.N.; Saidia, P. Expert-based ex-ante assessments of potential social, ecological, and economic impacts of upgrading strategies for improving food security in rural Tanzania using the ScalA-FS approach. Food Secur. 2017, 9, 1255-1270. [CrossRef]

14. Stuetz, W.; Schlörmann, W.; Glei, M. B-vitamins, carotenoids and $\alpha$-/ $\gamma$-tocopherol in raw and roasted nuts. Food Chem. 2017, 221, 222-227. [CrossRef] [PubMed]

15. WHO/FAO. Vitamin and Mineral Requirements in Human Nutrition: Report of a Joint FAO/WHO Expert Consultation, Bangkok, Thailand, 21-30 September 1998; WHO: Geneva, Switzerland, 2004.

16. Hongsibsong, S.; Stuetz, W.; Sus, N.; Prapamontol, T.; Grune, T.; Frank, J. Dietary exposure to continuous small doses of $\alpha$-cypermethrin in the presence or absence of dietary curcumin does not induce oxidative stress in male Wistar rats. Toxicol. Rep. 2014, 1, 1106-1114. [CrossRef] [PubMed]

17. Stuetz, W.; Carrara, V.I.; McGready, R.; Lee, S.J.; Erhardt, J.G.; Breuer, J.; Biesalski, H.K.; Nosten, F.H. Micronutrient status in lactating mothers before and after introduction of fortified flour: Cross-sectional surveys in Maela refugee camp. Eur. J. Nutr. 2012, 51, 425-434. [CrossRef] [PubMed]

18. Latta, M.; Eskin, M. A simple and rapid colorimetric method for phytate determination. J. Agric. Food Chem. 1980, 28, 1313-1315. [CrossRef]

19. Fruhbeck, G.; Alonso, R.; Marzo, F.; Santidrián, S. A modified method for the indirect quantitative analysis of phytate in foodstuffs. Anal. Biochem. 1995, 225, 206-212. [CrossRef]

20. Norhaizan, M.; Nor Faizadatul Ain, A. Determination of phytate, iron, zinc, calcium contents and their molar ratios in commonly consumed raw and prepared food in malaysia. Malays. J. Nutr. 2009, 15, 213-222.

21. Msuya, J.; Mamiro, P.; Weinberger, K. Iron, zinc and $\beta$-carotene nutrient potential of non-cultivated indigenous vegetables in Tanzania. In Proceedings of the International Symposium on Underutilized Plants for Food Security, Nutrition, Income and Sustainable Development, Arusha, Tanzania, 3-7 March 2008; pp. 217-222.

22. Djuikwo, V.N.D.; Ejoh, R.A.; Gouado, I.; Mbofung, C.M.; Tanumihardjo, S.A. Determination of major carotenoids in processed tropical leafy vegetables indigenous to Africa. Food Nutr. Sci. 2011, 2, 793-802. [CrossRef] 
23. Njeme, C.; Goduka, N.; George, G. Indigenous leafy vegetables (imifino, morogo, muhuro) in South Africa: A rich and unexplored source of nutrients and antioxidants. Afr. J. Biotechnol. 2014, 13, 1933-1942. [CrossRef]

24. Keding, G.; Weinberger, K.; Swai, I.; Mndiga, H. Diversity, Traits and Use of Traditional Vegetables in Tanzania; AVRDC-World Vegetable Center: Tainan, Taiwan, 2007.

25. De Pee, S.; West, C.; Permaesih, D.; Martuti, S.; Hautvast, J. Orange fruit is more effective than are dark-green, leafy vegetables in increasing serum concentrations of retinol and beta-carotene in schoolchildren in indonesia. Am. J. Clin. Nutr. 1998, 68, 1058-1067. [CrossRef]

26. Clevidence, B.; Paetau, I.; Smith, J.C. Bioavailability of carotenoids from vegetables. HortScience 2000, 35, 585-588.

27. Mashurabad, P.C.; Palika, R.; Jyrwa, Y.W.; Bhaskarachary, K.; Pullakhandam, R. Dietary fat composition, food matrix and relative polarity modulate the micellarization and intestinal uptake of carotenoids from vegetables and fruits. J. Food Sci. Technol. 2017, 54, 333-341. [CrossRef]

28. Van Het Hof, K.H.; West, C.E.; Weststrate, J.A.; Hautvast, J.G. Dietary factors that affect the bioavailability of carotenoids. J. Nutr. 2000, 130, 503-506. [CrossRef]

29. Weinberger, K.; Swai, I. Consumption of traditional vegetables in Central and Northeastern Tanzania. Ecol. Food Nutr. 2006, 45, 87-103. [CrossRef]

30. Kamal-Eldin, A.; Appelqvist, L.A. Variations in the composition of sterols, tocopherols and lignans in seed oils from four Sesamum species. J. Am. Oil Chem. Soc. 1994, 71, 149-156. [CrossRef]

31. Kim, Y.-N.; Giraud, D.W.; Driskell, J.A. Tocopherol and carotenoid contents of selected Korean fruits and vegetables. J. Food Compos. Anal. 2007, 20, 458-465. [CrossRef]

32. Rizvi, S.; Raza, S.T.; Ahmed, F.; Ahmad, A.; Abbas, S.; Mahdi, F. The role of vitamin E in human health and some diseases. Sultan Qaboos Univ. Med. J. 2014, 14, e157. [PubMed]

33. Mibei, E.K.; Ojijo, N.K.; Karanja, S.M.; Kinyua, J.K. Compositional attributes of the leaves of some indigenous African leafy vegetables commonly consumed in Kenya. Ann. Food Sci. Technol. 2011, 12, 146-154.

34. Nyaura, J.; Sila, D.; Owino, W. Vitamin C content of vegetable amaranth during modified atmospheric storage. In Proceedings of the 2013 JKUAT Scientific Technological and Industrialization Conference, Nairobi, Kenya, 14-15 November 2013.

35. Arasaretnam, S.; Kiruthika, A.; Mahendran, T. Nutritional and mineral composition of selected green leafy vegetables. Ceylon J. Sci. 2018, 47, 35-41. [CrossRef]

36. Lane, D.J.; Richardson, D.R. The active role of vitamin C in mammalian iron metabolism: Much more than just enhanced iron absorption! Free Radic. Biol. Med. 2014, 75, 69-83. [CrossRef] [PubMed]

37. Waldmann, A.; Koschizke, J.W.; Leitzmann, C.; Hahn, A. Dietary iron intake and iron status of German female vegans: Results of the German vegan study. Ann. Nutr. Metab. 2004, 48, 103-108. [CrossRef]

38. Prabhu, S.; Barrett, D.M. Effects of storage condition and domestic cooking on the quality and nutrient content of African leafy vegetables (Cassia tora and Corchorus tridens). J. Sci. Food Agric. 2009, 89, 1709-1721. [CrossRef]

39. Kinabo, J.; Mnkeni, A.; Nyaruhucha, C.; Msuya, J.; Ishengoma, J. Nutrients content of foods commonly consumed in Iringa and Morogoro regions. In Proceedings of the 2nd Collaborative Research Workshop on Food Security, Morogoro, Tanzania, 28-30 May 2003; pp. 28-30.

40. Schönfeldt, H.; Pretorius, B. The nutrient content of five traditional South African dark green leafy vegetables-A preliminary study. J. Food Compos. Anal. 2011, 24, 1141-1146. [CrossRef]

41. Steyn, N.; Olivier, J.; Winter, P.; Burger, S.; Nesamvuni, C. A survey of wild, green, leafy vegetables and their potential in combating micronutrient deficiencies in rural populations: Research in action. S. Afr. J. Sci. 2001, 97, 276-278.

42. Muyonga, J.H.; Aworh, O.C.; Kinyuru, J.; Manley, M.; Nansereko, S.; Nyangena, D.N. Nutritional and nutraceutical properties of traditional African foods. In Public Health, Disease and Development in Africa; Routledge: London, UK, 2018; pp. 229-244.

43. Ilelaboye, N.; Amoo, I.; Pikuda, O. Effect of cooking methods on mineral and anti nutrient composition of some green leafy vegetables. Arch. Appl. Sci. Res. 2013, 5, 254-260.

44. Lukmanji, Z.; Hertzmark, E.; Mlingi, N.; Assey, V.; Ndossi, G.; Fawzi, W. Tanzania Food Composition Tables; MUHAS-TFNC, HSPH: Dar es Salaam, Tanzania, 2008.

45. Annor, G.A.; Debrah, K.T.; Essen, A. Mineral and phytate contents of some prepared popular Ghanaian foods. SpringerPlus 2016, 5, 581. [CrossRef] [PubMed] 
46. Ma, G.; Li, Y.; Jin, Y.; Zhai, F.; Kok, F.; Yang, X. Phytate intake and molar ratios of phytate to zinc, iron and calcium in the diets of people in China. Eur. J. Clin. Nutr. 2007, 61, 368-374. [CrossRef] [PubMed]

47. Gupta, R.K.; Gangoliya, S.S.; Singh, N.K. Reduction of phytic acid and enhancement of bioavailable micronutrients in food grains. J. Food Sci. Technol. 2015, 52, 676-684. [CrossRef] [PubMed]

(C) 2019 by the authors. Licensee MDPI, Basel, Switzerland. This article is an open access article distributed under the terms and conditions of the Creative Commons Attribution (CC BY) license (http://creativecommons.org/licenses/by/4.0/). 